que nunca ha sido término común. Habrá que situar el origen de la bebida después de la introducción del té y del café en Europa, y la civilización francesa fué sin duda la que convirtió las antiguas tres copas de vino en tazas de café con aguardiente. Los marineros - gente que acepta más fácilmente las costumbres exóticas- adoptaron seguramente el uso francés de las tres tazas de café con aguardiente después de comer, y esto quizá desde el siglo xvir.

State University of New York,

L. B. BuCKLIN

Harpur College.

\title{
"IDEAS PICUDAS", “IDEAS REDONDAS": MAUPASSANT Y GANIVET
}

En un artículo reciente he indicado que a Ángel Ganivet se le habría ocurrido probablemente la imagen de ideas picudas al leer los ensayos de Unamuno publicados en 1895, En torno al casticismo ("La voluntad de estilo de Unamuno...", CuA, 12 (1953), núm. 3, p. 112). Sin negar ahora esta verosímil influencia unamuniana creo, sin embargo, que la fuente de la pareja de imágenes ganivetienses, ideas picudas, ideas redondas, se encuentra en el cuento de Maupassant, publicado en 1886, Mademoiselle Perle (incluído en el volumen de ese año, La petite Roque). He aquí el texto de Maupassant ${ }^{1}$ :

Mme Chantal, une grosse dame, dont toutes les idées me font l'effet d'être carrées à la façon des pierres de taille, avait coutume d'émettre cette phrase comme conclusion à toute discussion politique: "Tout cela est de la mauvaise graine pour plus tard". Pourquoi me suis-je toujours imaginé que les idées de Mme Chantal sont carrées? Je n'en sais rien; mais tout ce qu'elle dit prend cette forme dans mon esprit: un carré, un gros carré avec quatre angles symétriques. Il y a d'autres personnes dont les idées me semblent toujours rondes et roulantes comme des cerceaux. Dès qu'elles ont commencé une phrase sur quelque chose, ça roule, ça va, ̧̧a sort par dix, vingt, cinquante idées rondes, des grandes et des petites que je vois courir l'une derrière l'autre, jusqu'au bout de l'horizon. D'autres personnes aussi ont des idées pointues... Enfin, cela importe peu.

En el Idearium español (1897) empleó Ganivet las imágenes mencionadas en el siguiente texto (Obras completas, Aguilar, Madrid, 1943, t. 1, p. 237):

A esas ideas que incitan a la lucha las llamo yo ideas picudas; y, por oposición, a las ideas que inspiran amor a la paz las llamo redondas. Este libro que estoy escribiendo sólo contiene ideas redondas.

$\mathrm{Y}$ en una de sus cartas a Unamuno se atribuyó la originalidad de esas

${ }^{1}$ La petite Roque, Oeuvres complètes, Paris, 1909, pp. 115-116. Agradezco a los profesores R. Lida y M. Coindreau sus amables indicaciones para la preparación de esta nota. 
imágenes, fundándola en una vivencia personal (El porvenir de España, ibid., t. 2, p. 1075):

También le diré que el concepto de las ideas redondas que me sirvió de criterio para escribir el Idearium me lo sugirió mi primer oficio. Yo he sido molinero, y a fuerza de ver cómo las piedras andan y muelen sin salirse nunca de su centro, se me ocurrió pensar que la idea debe ser semejante a la muela del molino, que sin cambiar de sitio da harina, y con ella el pan que nos nutre, en vez de ser, como son las ideas de España, ideas picudas, proyectiles ciegos que no se sabe adónde van, y van siempre a hacer daño.

Las tres imágenes de Maupassant, idées carrées, idées rondes, idées pointues, quedan reducidas a dos en Ganivet, ideas redondas e ideas picudas, y esta última, simplemente mencionada en el texto francés, equivale en el español a las idées carrées. En efecto, idées carrées e ideas picudas se asemejan en lo rectilíneo y angular. Sin embargo, las diferencias son evidentes: las idées carrées del personaje de Maupassant, comparadas a piedras rectangulares, denotan sobre todo pesadez ("une grosse dame", "un gros carré") y fijeza moral, mientras que las ideas picudas de Ganivet son como pedruscos o proyectiles. Los españoles, según Ganivet, "transforman las ideas en instrumentos de combate" (Idearium, ed. cit., p. 236) y el personaje de Maupassant, en cambio, corta las discusiones políticas porque las ve como semillero de posteriores disensiones personales. Además, las idées rondes, comparadas al aro infantil, son la manifestación de la fluidez verbal, mientras que las ideas redondas, equiparadas a muelas de molino, representan la actividad espiritual útil y sociable. La preferencia de Ganivet por la imagen de ideas picudas se explica porque a él le interesaba marcar la oposición entre el carácter supuestamente belicoso de las ideas de la generalidad de los españoles y las suyas propias (ideas redondas).

Es muy probable que Ganivet conociera el cuento de Maupassant y que recordara esas imágenes al hacer su caracterización de la psicología social hispánica. Pudiera también tratarse de una simple coincidencia y que Ganivet hubiera sido sincero al atribuirse la originalidad de las imágenes mencionadas. ¿Podría también pensarse en el deseo, tan revelador del impulso estilístico de Ganivet, de presentar este posible fruto de sus lecturas como procedente de una experiencia vital no-literaria y de carácter cotidiano y manual? En todo caso, la comparación entre los textos de Maupassant y de Ganivet sirve para hacer resaltar los rasgos propios del estilo del escritor español. Las idées rondes de Maupassant se atribuyen impersonalmente a un conjunto social limitado ("d'autres personnes"), y en cambio las ideas picudas de Ganivet cobran categoría de negativo símbolo nacional ("como son las ideas en España, ideas picudas ..."), opuestas, además, a las propias ideas redondas del autor. Se da, por lo tanto, en el caso de Ganivet una forma similar a la de Unamuno de expresar su voluntad de estilo (véase el artículo citado, pp. 113114). El afán de Ganivet por redondear sus ideas ("El procedimiento que yo uso para redondear mis ideas...") es semejante al de Unamuno que quería llenar de nimbos su prosa. Y así como la imagen de nimbo, procedente conceptualmente de la estética simbolista, cobraba en los pri- 
meros escritos de Unamuno una significación a la vez estilística y éticosociológica, las ideas redondas de Ganivet, procedentes quizá del cuento de Maupassant, adquirían también un nuevo sentido, determinado simultáneamente por su voluntad de estilo y por su visión de la vida española ${ }^{2}$.

Bryn Mawr College.

Juan Marichal

\section{SOBRE EL CASAMIENTO DEL CID}

Ya estaba impreso mi artículo sobre "El casamiento del Cid" en el tomo I del Homenaje a Amado Alonso (NRFH, 7, 1953, 316-336) cuando pude consultar Los famosos y eroycos hechos del ynvencible y esforçado cavallero, onrra y flor de las Españas, el Cid Ruydiaz de Bivar, poema épico en octava rima publicado por Diego Jiménez de Ayllón en Amberes en 1568. Este poema representa una etapa curiosa entre el romancero y Guillén de Castro; el amor de Jimena ya está representado en él como anterior a la muerte del Conde por Rodrigo (p. $\left.2 \mathrm{v}^{\circ}\right)$ : esa invención no se debe, pues, a Guillén de Castro (lo observa con mucha razón BARbara Matulka, The Cid as a courtly hero, Columbia University, 1928, págs. 39-40) . En Jiménez de Ayllón, Jimena persigue a Rodrigo a pesar de quererlo, como en la forma última de la leyenda; pero, de acuerdo con la tradición, acaba pidiéndolo ella misma por marido. Lo interesante es cómo Jiménez de Ayllón, dentro de la nueva estructuración de la leyenda, subraya su sentido primitivo (p. $3 \mathrm{r}^{\mathrm{o}}$ ):
Tanto pudo el valor inestimable de don Rodrigo y de su altiva fama, que siendo el desamor incomparable que le tenía y tuvo aquella dama, bolvió con rostro alegre y agradable assí como al venado suele gama...

Véanse las interesantes observaciones que trae sobre nuestro tema G. Reynier, Mélanges Lanson, Paris, 1922, p. 221 . No me fué posible consul$\operatorname{tar}$ G. L. van Roosbroeck, The Cid theme in France in 160o, Minneapolis, 1920.

Paris.

Paul BÉNichou

2 En Granada la bella (Helsingfors, 1896; libro redactado en febrero de 1896) daba Ganivet el siguiente consejo a un hipotético campesino: "Pero si el empeño es irrevocable [el deseo de llevar guantes], no le queda a usted otro camino que venirse a vivir a la ciudad, andar entre cristales, romperse las esquinas y redondearse los ángulos con el trato social, y esperar tranquilo que algún día los guantes le vayan como la seda" (Obras completas, ed. cit., I, p. 4). Véase también en el artículo "Las ruinas de Granada" la referencia a cuatro tipos humanos: hombres "verticales", "horizontales", "curvos" y finalmente los "pesimistas" (de cráneo "aplanado y con pequeñas angulosidades ... , [hombre] aficionado a ir contra la corriente ... falta de adaptación al medio", ibid., II, pp. 718-719). 